\title{
PREPARASI ETOSOM EKSTRAK ETANOL BIJI KOPI (Coffea arabica L.) MENGGUNAKAN VARIASI KONSENTRASI SOYA LESITIN DAN ETANOL
}

\author{
Andi Nur Zam Zam ${ }^{1,2}$, Latifah Rahman ${ }^{1}$, Sartini ${ }^{1}$, Subehan Lallo ${ }^{1}$, Asnah Marzuki $^{1}$ \\ Fakultas Farmasi, Universitas Hasanuddin, Makassar \\ Jurusan Farmasi, Fakultas MIPA, Universitas Islam, Makassar
}

\section{Kata Kunci :}

Etosom, soya lesitin, ekstrak etanol biji kopi, uji permeasi

\begin{abstract}
ABSTRAK
Penelitian ini bertujuan untuk mendapatkan perbandingan konsentrasi antara soya lesitin dan etanol agar menghasilkan etosom ekstrak etanol biji kopi hijau dengan efisiensi penjerapan terbaik serta mengetahui perbedaan permeasi antara gel etosom ekstrak etanol biji kopi hijau dan gel ekstrak etanol biji kopi. Ekstraksi biji kopi hijau dilakukan dengan metode maserasi menggunakan pelarut etanol 70\%. Selanjutnya ekstrak diformulasikan dalam bentuk etosom menggunakan soya lesitin dengan konsentrasi yang divariasikan. Selanjutnya etosom diformulasikan dalam bentuk gel kemudian diuji laju permeasinya dan dibandingkan dengan gel ekstrak etanol biji kopi. Lipid yang digunakan adalah soya lesitin dan alkohol yang digunakan adalah etanol 95\%. Perbandingannya dipilih berdasarkan formula yang paling banyak menjerap ekstrak etanol biji kopi hijau. Optimasi penjerapan dilakukan dengan menaikkan konsentrasi soya lesitin dan etanol hingga diperoleh penjerapan optimum. Pengujian permeasi dilakukan dengan sediaan gel etosom berbasis karbopol dan menggunakan kulit manusia secara in vitro. Berdasarkan hasil penelitian, diperoleh etosom ekstrak etanol biji kopi hijau dengan bentuk Large Unilamellar Vesicles (LUV) dengan ukuran 0,63-12,08 $\mu \mathrm{m}$. Formula dengan perbandingan b/b soya lesitin : etanol (1:10) dapat menjerap ekstrak etanol biji kopi (EEBK). Uji permeasi menunjukkan bahwa total polifenol EEBK dalam sediaan gel etosom adalah 2,03 mg dalam waktu 240 menit dengan kecepatan lintas membran $1,37 \mathrm{mg} / \mathrm{menit} \mathrm{cm} 2$. Sedangkan permeasi EEBK dalam sedian gel ekstrak adalah 3,12 $\mathrm{mg}$ dalam waktu 240 menit dengan kecepatan lintas membran 1,23 mg/menit cm2.
\end{abstract}

\section{PENDAHULUAN}

Tanaman kopi (Coffea arabica L.) merupakan salah satu sumber antioksidan alami untuk tubuh manusia. Berdasarkan cara pengolahannya, dikenal kopi hijau dan kopi hitam. Kopi hijau (green coffee) adalah kopi yang belum mengalami proses pemanggangan menjadi kopi hitam (roasted coffe). Kandungan kimia utama kopi hijau adalah polifenol (5-0-caffeoylquinic acid atau asam klorogenat) sebesar 6-12 \% yang dikenal sebagai antioksidan poten pada biji kopi yang tidak disangrai (green coffee bean) dengan kadar kafein kurang dari 2\% (1). Proses pemanggangan dapat mengurai asam klorogenat menjadi asam quinat dan asam kafeat (2).

Telah banyak penelitian mengenai kafein dan asam klorogenat sebagai salah satu bahan aktif dalam sediaan topikal anti-selulit dan slimming $(2,3,4)$. Efikasi ekstrak biji kopi hijau sebagai suplemen penurun bobot badan menunjukkan bahwa konsumsi ektrak biji kopi hijau 180-200 mg per hari dapat membantu menurunkan bobot badan (2). Beberapa zat aktif antiselulit yang sering digunakan pada sediaan kosmetik topikal yaitu turunan metilxantin seperti kafein, teofilin, aminofilin, teobromin. Derivat metil xantin sebagai antiselulit bekerja dengan cara menghambat lipogenesis dan meningkatkan lipolisis melalui penghambatan aktivitas antilipolisis dan adenosin (inhibitor fosfodiesterase). Senyawa metilxantin yang berguna dan aman adalah kafein, umumnya digunakan pada konsentrasi $1-2 \%(5)$
Polifenol merupakan senyawa polar dan umumnya larut dalam pelarut polar. Molekul yang bersifat polar dan besar tidak dapat berpenetrasi dengan baik ke dalam stratum korneum. Untuk bioavailabilitas yang baik, produk alami harus memiliki keseimbangan yang baik antara sifat hidrofilik (melarut ke dalam cairan saluran pencernaan) dan sifat lipofilik (untuk menyeberangi biomembran lipid). Beberapa bahan alam seperti polifenol memiliki kelarutan yang baik dalam air, tetapi bagaimanapun sulit diabsorbsi (6). Absorbsi perkutan senyawa hidrofilik membutuhkan peningkat penetrasi (vesicular enhancher) salah satunya adalah sistem penghantar berbentuk vesikel. Salah satu sistem penghantaran obat yang dapat digunakan yaitu etosom. Etosom merupakan pembawa jenis vesikel halus dan lunak yang tersusun atas fosfolipid, alkohol konsentrasi tinggi dan air. Konsentrasi yang tepat dapat mengantarkan zat aktif secara transport pasif ke dalam lapisan kulit hingga mencapai sirkulasi sistemik. Beberapa keuntungan dari etosom adalah mampu meningkatkan konsentrasi obat di kulit, memungkinkan untuk molekul berukuran besar, secara luas diaplikasikan dalam kosmetik dan teknologi obat herbal, dapat menjerap semua jenis molekul obat seperti hidrofilik, lipofilik atau amfifilik. Etosom juga digunakan sebagai peningkat permeasi dari kulit sehingga obat mudah melintasi kulit. Selain itu biaya penyiapan etosom relatif lebih murah serta dapat dilakukan tanpa pemanasan (metode dingin) sehingga stabilitas bahan aktif terjaga (7). 
Oleh karena itu, penelitian ini bertujuan mendapatkan perbandingan konsentrasi antara soya lesitin dan etanol untuk menghasilkan etosom ekstrak etanol biji kopi hijau (Coffea arabica L.) dengan efisiensi penjerapan terbaik dan mengetahui perbedaan permeasi antara gel etosom ekstrak etanol biji kopi hijau (Coffea arabica L.) dan gel konvensional.

\section{METODE PENELITIAN}

\section{Alat dan Bahan}

Alat-alat yang digunakan dalam penelitian ini alat-alat gelas yang digunakan di laboratorium, Mikropipet, Timbangan analitik (Sartorius), lemari pendingin, blender (kirin®), Magnetic stirrer, Evaporator (Buchi Rotavapor R-220), Spektrofotometer (Thermo Scientific ${ }^{\circ}$ UV-1800), Viscometer (Brookfield, USA), $\mathrm{pH}$ meter (Universal instrument), Termometer, Sonikator, Alat difusi Franz, Sentrifuse (Thermo Scientific), Freeze Dryer (Buchi Lyovapor L-200) dan Mikroskop binokuler (Olympus CX23).

Bahan-bahan yang digunakan adalah biji kopi (Coffea arabica L.), etanol 70\%, reagen Folin-Ciocalteu, karbopol 940, propilen glikol, soy lecitin, metil paraben, trietanolamin, natrium hidroksida, asam gallat, kafein, kulit uji bagian penis dan dapar posfat

\section{Prosedur Kerja}

\section{Penyiapan Sampel Penelitian}

Biji kopi (Coffea arabica L.) kering digiling dengan menggunakan blender sehingga diperoleh serbuk kasar.

\section{Ekstraksi Polifenol dan Kafein Dari Biji Kopi}

Serbuk biji kopi ditimbang sebanyak 1 kg dimasukkan ke dalam wadah maserasi dan ditambahkan pelarut etanol 70\% sebanyak $5 \mathrm{~L}$. Wadah ditutup dan disimpan pada tempat yang terlindung dari cahaya. Dibiarkan selama tiga hari sambil diaduk sekali-sekali. Setelah tiga hari, kemudian disaring selanjutnya ampasnya dimaserasi kembali dengan pelarut etanol 70\% sebanyak 5 L. Filtrat ditampung dan kemudian dipekatkan menggunakan rotavapor, sehingga didapatkan ekstrak kental. Ekstrak dikeringkan menggunakan freezdryer sehingga diperoleh ekstrak kering.

Rendemen ekstrak dihitung menggunakan rumus sebagai berikut:

\section{Rendemen $=$ Berat ekstrak kental $/$ Berat biji kopi $\times 100 \%$}

\section{Pengukuran Total Polifenol Ekstrak Biji Kopi}

Ekstrak yang diperoleh kemudian dilakukan uji kuantitatif total polifenol menggunakan spektrofotometer UV-VIS dengan menggunakan asam gallat sebagai baku pembanding.

\section{Pengukuran Total Kafein Ekstrak Biji Kopi}

Ekstrak yang diperoleh kemudian dilakukan uji kuantitatif total kafein menggunakan spektrofotometer UV-VIS dengan menggunakan kafein murni sebagai baku pembanding.

\section{Penyiapan Etosom}

Soya lesitin didispersikan dalam air suling $30^{\circ} \mathrm{C}$ di dalam wadah tertutup. Selanjutnya dimasukkan ekstrak etanol biji kopi dan dihomogenkan dengan magnetic stirrer pada kecepatan $750 \mathrm{rpm}$ selama 5 menit hingga membentuk sistem koloidal. Propilen gilikol dan etanol 70\% masingmasing dipanaskan pada suhu $30 \mathrm{oC}$ kemudian ditambahkan ke dalam campuran sistem koloidal. Diaduk selama 5 menit hingga terbentuk suspensi vesikel etosom-ekstrak etanol biji kopi. Ukuran vesikel etosom diperkecil dengan sonikasi selama 15 menit.

\section{Karakterisasi Etosom}

\section{Penyiapan Sampel}

Suspensi vesikel etosom disimpan dalam lemari pendingin selama satu malam. Disentrifugasi dengan kecepatan 15.000 rpm selama 2 jam. Supernatannya diambil untuk mengukur kadar total polifenol dan kafein dalam etosom ekstrak etanol biji kopi yang tidak terjerap.

Perhitungan Efisiensi Penjerapan (Sentjurc, 1999)

Persentase penjerapan total polifenol dihitung dari rumus berikut:

\section{$\mathrm{EE}=(\mathrm{Qt}-\mathrm{Qs}) / \mathrm{Qt} \times 100 \%$}

EE adalah efisiensi penjerapan (entrapment efficiency), Qt adalah jumlah obat dalam EEBK yang ditambahkan dan Qs adalah jumlah obat yang terdeteksi di supernatan.

\section{Penetuan $\mathrm{pH}$}

$\mathrm{pH}$ gel ditentukan dengan menggunakan $\mathrm{pH}$ meter (Universal instrument). Elektroda diletakkan di dalam wadah gel sehingga elektroda tertutupi oleh gel etosom. Pembacaan dilakukan pada suhu ruang.

\section{Viskositas.}

Viskositas ditentukan menggunakan viscometer (Brookfield, USA) menggunakan spindle 64, kecepatan $3 \mathrm{rpm}$.

\section{HASIL DAN PEMBAHASAN}

Sampel yang digunakan adalah sampel biji kopi hijau dengan berat 1000 gram. Biji kopi dicuci untuk menghilangkan kotoran yang tertinggal, lalu diblender. Setelah itu sampel dikeringkan dengan cara diangin-anginkan kemudian diekstraksi dengan pelarut polar Etanol 70\% karena senyawa polifenol yang akan ditarik bersifat polar dan diaduk seringsering agar proses penarikan senyawa lebih baik, ampas hasil maserasi lalu dimaserasi kembali (remaserasi) selama 2x24 jam dan dilakukan pengadukan. Hasil remaserasi lalu di rotavapor untuk menghilangkan sisa pelarut sehingga diperoleh ekstrak kental. Selanjutnya dilakukan proses pengeringan menggunakan alat freezdryer untuk memperoleh ekstrak kering.

Berdasarkan hasil penelitian, ekstraksi biji kopi hijau dengan metode maserasi menggunakan pelarut polar etanol $70 \%$ menghasilkan rendamen sebesar 6,14\% dengan kadar total polifenol sebesar $15,5 \%$ dan kadar kafein sebesar $20,78 \%$. Ekstrak kering yang telah diperoleh selanjutnya diformulasikan menjadi etosom dalam empat formula yaitu formula A, B, C dan D dengan perbandingan soya lesitin 1-4\%

\begin{tabular}{|c|c|c|c|}
\hline Ekstrak & Berat (g) & Rendemen (\%) & $\begin{array}{c}\text { Total } \\
\text { Polifenol }\end{array}$ \\
\hline Etanol $70 \%$ & 61,4 & 6,14 & $15,51 \%$ \\
\hline \multicolumn{4}{|c|}{$\begin{array}{l}\text { Tabel 2. Hasil Pengukuran Total Kafein dari Ekstrak Etanol Biji Kop } \\
\text { Hijau }\end{array}$} \\
\hline Ekstrak & Berat (g) & Rendemen (\%) & Total Kafein \\
\hline Etanol $70 \%$ & 61,4 & 6,14 & $20,78 \%$ \\
\hline
\end{tabular}

Hasil pengukuran vesikel etosom bervariasi antara 0,63-12,1 $\mu \mathrm{m}$. Unit struktural dan fungsional dari nanotekhnologi 
dikenal sebagai nanopartikel. Partikel kasar kisaran ukurannya antara $2.500-10.000$ nanometer, partikel halus kisarannya antara $100-2.500$ nanometer dan partikel ultrafine kisarannya antara 1 - 100 nanometer (10). Berdasarkan ukurannya, maka ukuran vesikel yang diperoleh termasuk partikel halus. Adapun bentuk etosom yang dihasilkan adalah vesikel besar lapis tunggal atau Large Unilamellar Vesicle (LUV). Bentuk vesikel dapat ditentukan berdasarkan metode pembuatan yang dipilih. Metode dingin sering digunakan untuk menjerap obat yang bersifat hidrofilik karena mampu menjerap lebih banyak obat ke dalam kompartemen hidrofilik vesikel, yaitu fase air yang terdapat pada inti vesikel (9).

\begin{tabular}{cccccc} 
Tabel 3. Formula Etosom EEBK & & & \\
\hline Formula & $\begin{array}{c}\text { EEBK } \\
\text { (g) }\end{array}$ & $\begin{array}{c}\text { Soya } \\
\text { Lesitin } \\
\text { (g) }\end{array}$ & Propilenglikol & Etanol & $\begin{array}{c}\text { Air } \\
\text { (g) }\end{array}$ \\
\hline A & 2 & 1 & 1 & 10 & 86 \\
B & 2 & 2 & 1 & 20 & 75 \\
C & 2 & 3 & 1 & 30 & 64 \\
D & 2 & 4 & 1 & 40 & 53 \\
\hline
\end{tabular}

\begin{tabular}{|c|c|c|c|c|c|}
\hline Formula & Warna & Homogenitas & Tekstur & $\begin{array}{l}\text { Viskositas } \\
\text { (centipoise) }\end{array}$ & $\mathrm{pH}$ \\
\hline $\begin{array}{c}\text { Gel } \\
\text { Etosom }\end{array}$ & $\begin{array}{l}\text { Kuning } \\
\text { muda }\end{array}$ & Homogen & Lembut & 179,66 & 6,25 \\
\hline $\begin{array}{c}\text { Gel } \\
\text { Kontrol }\end{array}$ & $\begin{array}{l}\text { Kuning } \\
\text { kecoklatan }\end{array}$ & Homogen & Lembut & 97,66 & 6,52 \\
\hline
\end{tabular}

Selanjutnya etosom EEBK diformulasikan dalam bentuk sediaan semi padat yaitu gel. Formula gel dapat dilihat pada Tabel 3. Karbopol 940 secara umum digunakan sebagai bahan pembentuk gel dalam sistem etosom. Polimer jenis ini menunjukkan kompatibilitas yang baik dengan etosom, memperbaiki viskositas dan bioadesif bahan. Formula A yang memiliki persentase efisiensi penjeapan tertinggi sehingga dipilih untuk diformulasi menjadi sediaan gel. Basis gel yaitu karbopol 2\% dan trietanolamin 0,5\% sebagai bahan penstabil gel. Selain itu, pengawet yang digunakan adalah metil paraben sebesar 0,01\%. Digunakan pula humektan yaitu propilen glikol dengan konsentrasi 15\%. Dibuat formulasi gel EEBK sebagai kontrol dengan komposisi formula yang sama dengan gel etosom EEBK.

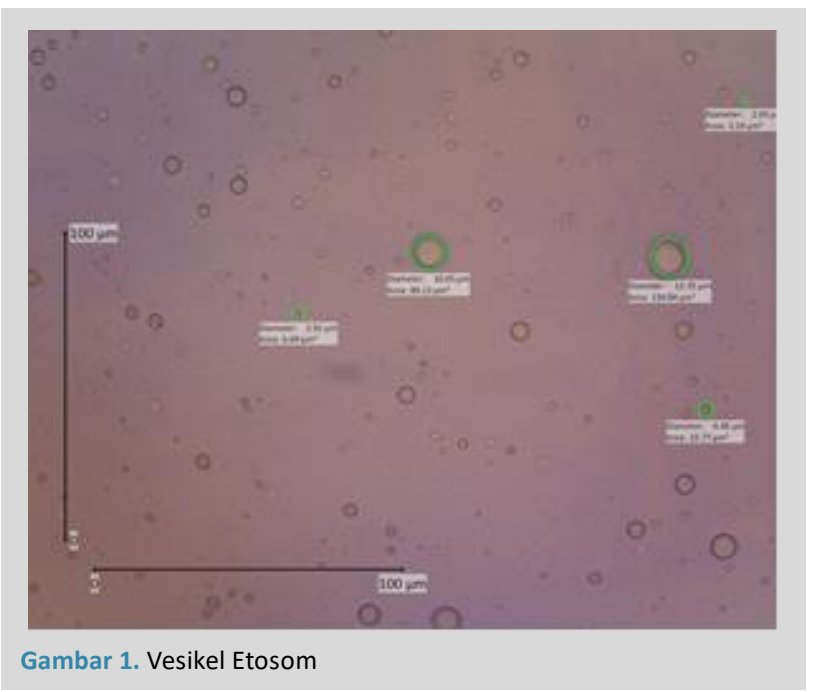

Berdasarkan uji difusi, diperoleh permeasi sediaan gel etosom sebesar 2,03 mg dalam waktu 240 menit dengan kecepatan lintas membran $1,37 \mathrm{mg} /$ menit $\mathrm{cm}^{2}$. Nilai $\mathrm{r}$ adalah
0,92 yang berarti memiliki koefisien korelasi sangat kuat. Sedangkan pada gel kontrol diperoleh sebesar 3,12 mg dalam waktu 240 menit dengan kecepatan lintas membran 1,23 $\mathrm{mg} /$ menit $\mathrm{cm}^{2}$. Nilai $\mathrm{r}$ adalah 0,59 yang berarti koefisien korelasinya sedang.

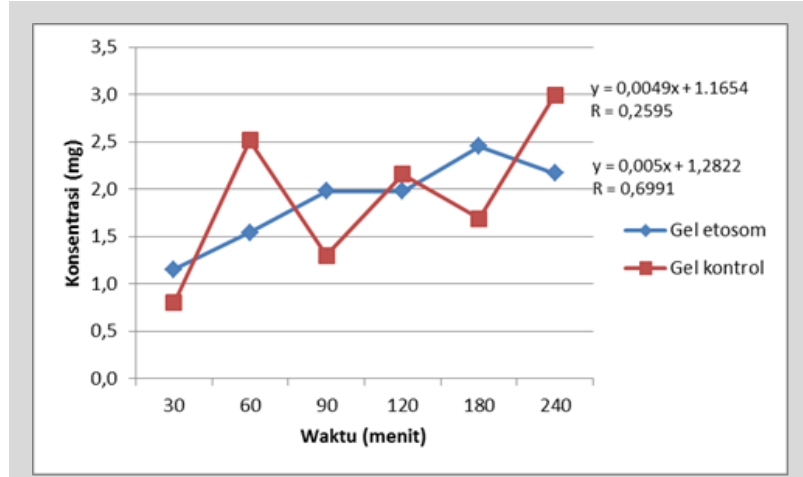

Gambar 2. Permeasi in vitro kafein EEBK

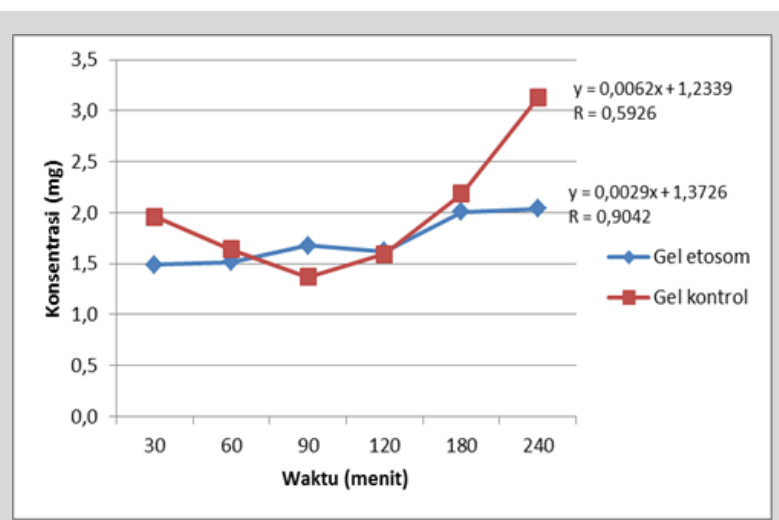

Gambar 3. Permeasi in vitro polifenol EEBK

\section{KESIMPULAN}

Formula A dengan perbandingan konsentrasi soya lesitin : etanol (1:10) diperoleh etosom dengan bentuk Large Unilamellar Vesicles (LUV) dengan ukuran 0,63-12,1 $\mu \mathrm{m}$. Permeasi total polifenol EEBK dalam sediaan gel etosom adalah 2,03 mg dalam waktu 240 menit dengan kecepatan lintas membran $1,37 \mathrm{mg} /$ menit $\mathrm{cm} 2$. Sedangkan permeasi EEBK dalam sedian gel ekstrak adalah 3,12 mg dalam waktu 240 menit dengan kecepatan lintas membran $1,23 \mathrm{mg} /$ menit $\mathrm{cm} 2$. Permeasi total kafein EEBK dalam sediaan gel etosom adalah 2,55 mg dalam waktu 240 menit dengan kecepatan lintas membran $1,28 \mathrm{mg} /$ menit $\mathrm{cm} 2$. Sedangkan permeasi EEBK dalam sedian gel ekstrak adalah 2,99 $\mathrm{mg}$ dalam waktu 240 menit dengan kecepatan lintas membran 1,16 mg/menit $\mathrm{cm} 2$.

\section{UCAPAN TERIMA KASIH}

Penulis mengucapkan terima kasih kepada LPDP Indonesia atas bantuan pendanaan. Penulis juga berterima kasih kepada Fakultas Farmasi Universitas Hasanuddin atas dukungan moril dan sarana selama penulis melakukan penelitian

\section{DAFTAR PUSTAKA}

1. Lupi, O., Semenovitch, I.J., Treu, C., Bottino, D. \& Bouskela, E., 2006 Evaluation of the effects of caffeine in the microcirculation and edema on thighs and buttocks using the orthogonal polarization spectral imaging and clinical parameters, J Cosmet Dermatol.Covic, A., Goldsmith, D., Segall, L., Stoicescu, C., Lungu, S., Volovat, C., et al. Rifampicin-induced acute renal failure: a series of 60 patients. Nephrology, dialysis, transplantation: official publication of the European Dialysis and Transplant Association-European Renal Association, 1998;13(4): $924-$ 929. 
2. Sainio, E.L., Rantanen, T. \& Kanerva, L. 2000. Ingedients and safety of cellulite creams. Eur. J. Dermatol., 10: 596 - 603.Cadenas, E., and Davies, K.J. Mitochondrial free radical generation, oxidative stress, and aging1. Free Radical Biology and Medicine, 2000;29(3-4): 222-230.

3. Rawlings, A.V. (2006). Cellulite and its treatment. Int. J Cosmet. Sci., 28: 175 - 190.Chen, R., Wang, J., Zhang, Y., Tang, S., and Zhan, S. Key factors of susceptibility to anti-tuberculosis drug-induced hepatotoxicity Archives of toxicology, 2015;89(6): 883-897.

4. Onakpoya, I., Terry, R., \& Ernst, E. 2011. The use of geen coffee extract as a weight loss supplement: A systematic reviev and meta-analysis of randomized clinical trials. Gastroent. Res. Pract.Ayala, A., Muñoz, M.F., and Argüelles, S. Lipid peroxidation: production, metabolism, and signaling mechanisms of malondialdehyde and 4-hydroxy-2-nonenal. Oxidative medicine and cellular longevity, 2014.

5. Cho AS, Jeon SM, Kim MJ,. Yeo, J., Seo, KI., Choi, MS., \& Lee, MK. 2010. Chlorogenic Acid Exhibits Anti-Obesity Property and Improves Lipid Metabolism in High-Fat Diet-Induced-Obese Mice. Food and Chemical Toxicology,48 (3): 937-43Djide, M.N., Sartini, Amir., M.N., and Juniarti, N.. Pengembangan Formula Ekstrak Kelopak Bunga Rosella (Hibiscus sabdariffa L.) Terstandar Sebagai Terap Alternatif/Supportif dalam Mengatasi Resistensi Obat Antituberkulosis. (Laporan Penelitian). Makassar: Universitas Hasanuddin.2017
6. Manach C., Scalbert A., Morand C., Rémésy C., Jiménez L., 2004, Polyphenols: food sources and bioavailability. Am J Clin Nutr.Fakeye, T.O., Pal, A., Bawankule, D., Yadav, N., and Khanuja, S. Toxic effects of oral administration of extracts of dried calyx of Hibiscus sabdariffa Linn.(Malvaceae). Phy totherapy research, 2009;23(3): 412-416.

7. Toitou dan Barry. 2007. Enhancement in Drug Delivery. United States of Amerika: CRC Press, New York.Hopkins, A.L., Lamm, M.G., Funk, J.L., and Ritenbaugh, C. Hibiscus sabdariffa L. in the treatment of hypertension and hyperlipidemia: a comprehensive review of animal and human studies. Fitoterapia, 2013;85: 84-94.

8. Sentjurc, 1999, Liposomes As a Topical Delivery System: The Role of Size on Transport Studies by the EPR Imaging Method. J. Control Rel, (Online) Khalili, H., Dashti-Khavidaki, S., Rasoolin ejad, M., Rezaie, L., and Etminani, M. Anti-tuber culosis drugs related hepatotoxicity; incidence, risk factors, pattern of changes in liver enzymes and outcome. Daru, 2009;17(3).

9. Ashis, R., 2010, Ethosomes: Novel Approach in Transdermal Drug Delivery System, Reseach Journal of Pharmaceutical Dosage Form and Technology, Vol. 02, No. 01.

10. Tiwari G. Preparation and characterization of Ketoconazole Encapsulated Liposome and Ethosome: a Comparative Study (Tesis). National Institute of Technology. Rourkela. India. 2013. 